Syntax Literate: Jurnal Ilmiah Indonesia p-ISSN: 2541-0849

e-ISSN: 2548-1398

Vol. 6, No. 2, Februari 2021

\title{
KEPEMIMPINAN PROFETIK SATGAS PENANGANAN COVID-19 DI KOTA YOGYAKARTA
}

\author{
Heri Susanto, Hadi Suyono, Khoiruddin Bashori dan Nina Zulida Situmorang \\ Universitas Ahmad Dahlan, Indonesia \\ Email: hs7787@gmail.com, hatijernih06@gmail.com, psy.uad.ac.id dan \\ nzsitumorang@gmail.com
}

\begin{abstract}
This study aims to determine the effectiveness of prophetic leadership in dealing with the Covid-19 crisis which affects all areas of life. This study uses a qualitative method with a case study approach. The sampling technique used was purposive sampling. The data collection technique used is in-depth interviews with the help of a voice recorder. The form of interview guidelines that will be conducted by researchers is semi-structured. The number of subjects who participated in this study were three subjects with one significant others. The results of this study were obtained through content analysis interpretation. The results showed that prophetic leadership was effective in dealing with the pandemic crisis with the Fathonah aspect as the culmination of the other three aspects, namely sidiq, amana and tabliq. From this research, the prophetic leadership of the Covid-19 Handling Task Force in the City of Yogyakarta was effective in suppressing the Covid-19 distribution rate until August. In September, several central government decisions prevented the Covid-19 Response Task Force from implementing prophetic leadership.
\end{abstract}

Keywords: leadership prophetyc; covid-19; crisis

\section{Abstract}

Penelitian ini bertujuan untuk mengetahui efektivitas kepemimpinan profetik dalam menangani krisis Covid-19 yang berdampak pada semua bidang kehidupan. Penelitian ini menggunakan metode kualitatif dengan pendekatan studi kasus. Teknik sampling yang digunakan adalah dengan Purposive sampling. Teknik pengumpulan data yang digunakan adalah wawancara mendalam (in-depth interview) dengan bantuan alat perekam suara Adapun bentuk pedoman wawancara yang akan dilakukan peneliti adalah semi terstruktur. Jumlah subyek yang ikut berpartisipasi dalam penelitian ini adalah tiga subjek dengan satu significant others. Hasil penelitian ini diperoleh melalui interprestasi analisis isi (content analysis). Hasil penelitian menunjukkan bahwa kepemimpinan profetik efektif dalam menangani krisis pandemi dengan aspek Fathonah sebagai puncak dari ketiga aspek lain yaitu sidiq, amana dan tabliq. Dari penelitian ini kepemimpinan profetik Satgas Penanganan Covid-19 di Kota Yogyakarta efektif dalam menekan angka sebaran Covid-19 sampai dengan bulan Agustus. Pada bulan September, beberapa keputusan pemerintah pusat membuat Satgas Penanganan Covid-19 tidak bisa menerapkan kepemimpinan profetik. 
Kata Kunci: kepemimpinan profetik; covid-19; krisis

\section{Coresponden Author}

Email: hs7787@gmail.com

Artikel dengan akses terbuka dibawah lisensi

\section{Pendahuluan}

Covid 19 yang melanda dunia sejak awal 2020 telah menyebabkan krisis multi bidang. Khususnya Negara-negara yang tidak memiliki tata kelola penanganan yang siap dan antisipatif. Menurut (Mas'udi \& Winanti, n.d.), COVID-19 telah melahirkan krisis tata kelola dan kebijakan penanganan pandemi hampir di seluruh negara, terlepas dari status kemajuan ekonomi dan teknologi, serta kehandalan sektor pelayanan kesehatan, menghadapi ketidakpastian dan ketidakyakinan dalam menangani COVID19. Sistem manajemen krisis standar seolah kehilangan relevansi, memaksa pemerintah di berbagai negara mengambil kebijakan yang cenderung bersifat trial and error. COVID-19 melahirkan tantangan tata kelola krisis pandemi yang bersifat tidak terduga dalam konteks global.

Kepemimpinan yang efektif pun akhirnya menjadi penentu dari negara-negara di dunia dalam menangani pandemi. Menurut (Guest, Del Rio, \& Sanchez, 2020), pemimpin harus tegas dengan mengajak masyarakat untuk tinggal di rumah yang kemudian diwujudkan dalam peraturan secara nasional, peningkatan pengujian SARSCoV-2 secara cepat, dan peningkatan kapasitas perawatan kesehatan untuk merespons yang bergejala positif merupakan wujud komitmen pemimpin.

Di Jerman menjadi salah satu negara di Eropa yang sukses menangani pandemi. menggunakan sistem welfare state (WS). Teori ini mengedepankan kepemimpinan nasional menjadi variabel penting, penganan krisis SARS-Cov-2. Teori WS menjelaskan salah satu contoh keputusan besar pemimpin selama krisis akan mempengaruhi dan menentukan negara keluar krisis (Susanto, 2020).

Saat situasi pandemi COVID-19, pemerintah memiliki tugas yang saling bertentangan. Mereka bertanggung jawab atas keselamatan dan kesejahteraan dasar rakyatnya. Peningkatan kesehatan rakyat pasti berdampak buruk karena merugikan ekonomi, mata pencaharian, dan sebaliknya. Pemerintah juga bertanggung jawab untuk melindungi warganya dari pembatasan utama kebebasan sipil dan otonomi pribadi. Mereka bertanggung jawab untuk memperlakukan semua orang secara setara, namun beberapa instrumen pengendalian pandemik menyerang kelompok yang sudah rentan lebih keras daripada populasi lainnya (Haÿry, 2020).

kepemimpinan menurut (Riyono, 2015), memiliki sifat-sifat antara lain: intelegensi, dominasi, kepercayaan diri, energi-aktivitas dan pengetahuan terhadap tugas. Pada pendekatan perilaku, sifat yang penting adalah berfungsi tidaknya kelompok tersebut. Berfungsinya kelompok tersebut bergantung pad ahubungan antar manusianya dan hubungan dengan pekerjaannya. Pada pendekatan situasional, sifat 
kepemimpinan sangat bergantung pada tingkat aspirasi dan orientasi kelompok tersebut. Ki Hajar Dewantoro.

Ada lima pendekatan dalam mengkaji teori kepemimpinan, yaitu pendekatan ciri sifat (trait approach), perilaku (behavior approach), kekuatan pengaruh (powerinfluence approach), situasional (situational approach), dan pendekatan integratif

Kepemimpinan profetik mengedapankan kemampuan seseorang untuk mempengaruhi orang lain mencapai tujuan sebagaimana para nabi dan rosul (prophet) melakukannya (Adz-Dzakiey, Budiharto, Kurniawan, Riyono, 2005).

Kepemimpinan profetik secara teoritis adalah kepemimpinan yang didasarkan pada pengalaman hidup nabi. Kepemimpinan yang memimpin semua aspek dan elemennya dalam kehidupan dan kepemimpinan dalam segala keadaan, proses pengambilan keputusan dan keahlian manajerial Nabi, Nabi membangsun model kepemimpinan dan membangun pemimpin - pengikut dalam kerjasama yang saling menguntungkan (Maheran Nik Muhammad, 2015).

Sebagai dasar dalam menerapkan kepemimpinan profetik, Adapun menurut ( Fadhli, 2018), prinsip-prinsip atau dasar dasar kepemimpinan dalam Islam adalah sebagai berikut:

a) Prinsip tauhid. Prinsip tauhid merupakan salah satu prinsip dasar dalam kepemimpinan Islam. Sebab perbedaan akidah yang fundamental dapat menjadi pemicu dan pemacu kekacauan suatu umat. Oleh sebab itu, Islam mengajak kearah satu kesatuan akidah diatas dasar yang dapat diterima oleh semua lapisan masyarakat, yaitu tauhid.

b) Prinsip musyawarah (Syuro'). Musyawarah berarti mempunyai makna mengeluarkan atau mengajukan pendapat. Dalam menetapkan keputusan yang berkaitan dengan kehidupan berorganisasi dan bermasyarakat musyawarah dalam konteks membicarakan persoalanpersoalan tertentu dengan anggota masyarakat, termasuk didalamnya dalam hal berorganisasi.

c) Prinsip keadilan (Al-'adalah). Dalam mengatur kepemimpinan, keadilan menjadi suatau keniscayaan, sebab kepemimpinan dibentuk antara lain agar tercipta masyarakat yang adil dan makmur. Jadi, sistem kepemimpinan Islam yang ideal adalah sistem yang mencerminkan keadilan yang meliputi persamaan hak didepan umum, keseimbangan (keproposionalan) dalam memanage stakeholder yang dipimpinnya.

d) Dasar Persatuan Islamiyyah (Ukhuwah Islamiyah). Prinsip ini untuk menggalang dan mengukuhkan semangat persatuan dan kesatuan umat Islam.

Dari teori tersebut, (Budiharto dan Himam, 2006) menemukan konstruk kepemimpinan profetik terdiri dari empat dimensi yaitu sidiq, amanah, tabligh, dan fathonah. Dari keempat dimensi ini, terdapatkan satu aspek sebagai pembeda dengan tiga aspek lainnya, yaitu berpedoman pada nurani \& kebenaran (conscience centred) sebagai istilah kunci aspek sidiq, profesional dan komitmen (highly committed) sebagai istilah kunci aspek amanah, ketrampilan komunikasi (communication skills) sebagai 
istilah kunci aspek tabligh, dan mampu mengatasi masalah (problem solver) sebagai istilah kunci aspek fathonah.

\section{Metode Penelitian}

Penelitian ini adalah penelitian yang besifat kualitatif. Penelitian yang digunakan yaitu penelitian kualitatif deskriptif. Penelitian kualitatif deskriptif adalah berupa penelitian dengan metode atau pendekatan studi kasus (case study). Penelitian ini memusatkan diri secara intensif pada satu obyek tertentu yang mempelajarinya sebagai suatu kasus. Data studi kasus dapat diperoleh dari semua pihak yang bersangkutan, dengan kata lain dalam studi ini dikumpulkan dari berbagai sumber (Nawawi, Osman, Annuar, Khalid, \& Yusoff, 2003).

Penelitian ini memilih metode purposive sampling sesuai dengan kebutuhan dan realitas di lapangan. kriteria khusus agar sampel yang diambil nantinya sesuai dengan tujuan penelitian dapat memecahkan permasalahan penelitian serta dapat memberikan nilai yang lebih representatif. Sehingga teknik yang diambil dapat memenuhi tujuan sebenarnya dilakukannya penelitian.

Menurut (Arikunto, 2019) pengertiannya adalah: teknik mengambil sampel dengan tidak berdasarkan random, daerah atau strata, melainkan berdasarkan atas adanya pertimbangan yang berfokus pada tujuan tertentu.

Penelitian kualitatif ini bersifat deskriptif, sumber data primer adalah penelitian yang melakukan tindakan dan anak yang menerima tindakan. Sedangkan sekunder berupa data hasil wawancara, observasi, dokumentasi serta triangulasi (Moleong, 2019).

Wawacara dilakukan pada 15 Januari 2021 sampai 5 Februari 2021 yang dipilih sebagai subyek penelitian Wakil Wali Kota Yogyakarta atau Ketua Satgas Penanganan Covid-19 Heroe Poerwadi, Kepala Satpol PP Kota Yogyakarta Agus Winarto, Kepala Dinas Kesehatan Kota Yogyakarta Emma Rahmi Aryani, dan significant others Ketua LPMK se-Kota Yogyakarta Haryanto ST, MM

\section{Hasil dan Pembahasan}

\section{A. Hasil}

Satgas Penanganan Covid-19 merupakan wujud dari perintah Menteri Dalam Negeri dalam surat edaran 440/5184/SJ Tentang Pembentukan Satuan Tugas Penanganan Corona Virus Disease D/SEASE 2019 (COV|D-19) Daerah. Berdasarkan ketugasan sesuai dengan SE tersebut, Satgas memiliki tugas pokok koordinasi penanganan dan pencegahan. 


\section{Gambar 1 \\ Struktur Organisasi Satgas Penanganan Covid-19 di Kota Yogyakarta}

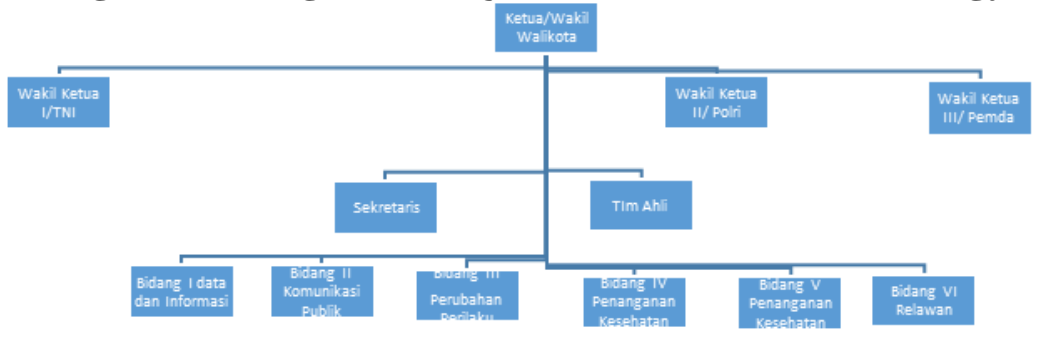

Satgas Penanganan Covid-19 yang merupakan lembaga ad-hoc dengan berisikan Organisasi Perangkat Daerah (OPD), Kepolisian dan TNI menerapkan Kepemimpinan Profetik dengan menyesuaikan fungsi dan tugasnya sesuai dengan Surat Edaran Menteri Dalam Negeri Nomor 440/5184/SJ.

Dalam SE tersebut dalam poin ketiga dijelaskan, Satgas Covid-19 daerah memiliki tugas antara lain:

a. Melaksanakan dan mengendalikan implementasi kebijakan strategis yang berkaitan dengan penanganan COVID-19 di daerah.

b. Menyelesaikan permasalahan pelaksanaan kebijakan strategis yang berkaitan dengan penanganan COVID-19 di daerah.

c. Melakukan pengawasan pelaksanaan kebijakan strategis yang berkaitan dengan penanganan COVID-19 di daerah.

d. Menetapkan dan melaksanakan kebijakan serta langkah-langkah lain yang diperlukan dalam rangka percepatan penanganan COVID-19 di daerah.

e. Komando dan kendali penanganan COVID-19 berada di bawah Kasatgas penanganan COVID-19 Nasional/Kepala Badan Nasional Penanggulangan Bencana (BNPB).

Dalam wawancara yang dilakukan dengan ketiga subjek dan satu significant others, dalam penanganan Covid-19 yang mulai masuk Indonesia pada bulan Maret, Satgas Penanganan Covid-19 saat itu menekankan tugas utama dalam tidak menimbulkan kepanikan di masyarakat.

Kemudian, setelah tidak terjadi kepanikan, Satgas Penanganan Covid-19 mulai meningkatkan dengan menumbuhkan kesadaran di masyarakat akan bahaya Covid-19. Maka, Satgas Penanganan Covid-19 Kota Yogyakarta sejak awal merapkan aspek sidiq yaitu berpedoman pada nurani yang berarti jujur atau berintegritas

Kejujuran dalam menginformasikan sesuai dengan apa yang terjadi yaitu virus Covid-19 telah masuk ke Kota Yogyakarta dilakukan Satgas Penanganan Covid-19 yang dilakukan Ketua Satgas Penanganan Covid-19 Heroe Poerwadi sekaligus Wakil Wali Kota: "Informasi yang diberikan ini semuanya, dari mulai 
anggaran yang ada lalu, kebijakan pemerintah pusat, DIY, dan kebijakan dari pemkot. Kalau memang berbeda, kami sampaikan alasannya. Akan tetapi, dari kebijakan yang kami lakukan memang tetap harus mengikuti aturan di atasnya. Mungkin, kami lebih mempertimbangkan aspek kearifan lokal".

Selain dengan kejujuran dalam penyampaikan informasi, Satgas Penanganan Covid-19 berusaha untuk selalu menjaga integritasnya seperti saat kebijakan pembukaan jasa pariwisata yaitu hotel dan restoran. Kedua sarana penunjang pariwisata itu, wajib untuk memiliki rekomendasi sertifikasi nyaman dan aman atau telah memenuhi syarat menerapkan protokol kesehatan untuk membuka usaha.

"Bagi hotel dan restoran wajib untuk mendapatkan sertifikasi kelaikan dengan menerapkan standard protokol kesehatan dengan baik, penyemprotan, dan tentu mereka (wisatawan) yang akan ke hotel wajib untuk memiliki hasil test (Covid-19) atau surat sehat. Alhamdulillah, dari PHRI menyambut positif. Di luar PHRI itu yang kehadiran mereka (wisatawan) tidak terkontrol".

Dalam penegakkan peraturan, Satpol PP menjadi ujung tombak dari pencegahan penyebaran Covid-19. Agus Winarto menjelaskan, agar masyarakat tidak melanggar, Satpol PP harus bisa menjaga integritas.

"Ini tadi Pak Noviar (Kepala Satpol PP DIY) minta bagaimana kalau Malioboro (toko dan PKL) diberikan keleluasaan untuk masih membuka toko seperti biasaya. Saya sampaikan, silahkan kalau mau didemo pelaku usaha di luar Malioboro. Akhirnya menyerahkan kepada kami pelaksanaan di lapangan”.

Kejujuran Juga Dilaksanakan Dinas Kesehatan Kota Yogyakarta Yang Merupakan Salah Satu Bagian Terpenting Dari Satgas Penanganan Covid-19 Di Kota Yogyakarta. Kepala Dinkes Kota Yogyakarta Emma Rahmi Aryani Menceritakan, Tanpa Kejujuran Sulit Bisa Menangani Kendala Penanganan Covid19 Di Lapangan.

"Seperti diawal ada kekurangan Alat Pelindung Diri (APD), itu bukan karena kami tidak ada uang untuk membeli. Saat itu belum ada kebijakan dari pemerintah pusat untuk realokasi anggaran. Kami untuk membeli harus menunggu. Kami sampaikan apa adanya kondisi keuangannya, dan alhamdulillah, banyak masyarakat yang peduli dengan membelikan APD untuk nakes (tenaga kesehatan)".

Dinkes Kota Yogyakarta juga menjaga integritas dalam penanganan Covid-19 ini. Mereka menindak tegas salah satu rumah sakit yang menerapkan harga rapid test jauh dibawah ketentuan.

"Ada rumah sakit yang akhirnya kami berikan peringatan karena masih menjual rapid test antibody dan yang menghargai rapid test antigen di bawah pasaran. Kami tegaskan, jangan ada yang mengambil keuntungan saat kesempatan. Kesehatan pasien nomer satu. Kalau memang rapid test antibody sudah tidak diperlukan ya berikan saja gratis".

Bagi masyarakat, khususnya Lembaga Pemberdayaan Masyarakat Kelurahan (LPMK), integritas teruji saat pembagian bantuan sembako. Ketua LPMK se-Kota 
Yogyakarta Hariyanto menjelaskan proses pembagian bantuan baik dari swasta maupun pemerintah.

"Kami sampaikan sampai tingkat RT dan RW yang merupakan pesan dari Pak Heroe bahwa bantuan ini harus tersalur kepada yang benar-benar berhak menerima. Terutama bantuan dari pemkot dan swasta yang penunjukkannya melibatkan RT/RW. Parameternya sangat banyak untuk yang berhak menerima, terutama terkena dampak langsung pandemi”.

1. Aspek Amanah

Menurut (Budiharto \& Himam, 2006) amanah merupakan bentuk dari profesional dan komitmen tinggi terhadap masyarakat yang mereka pimpin. Satgas Penanganan Covid-19 menjalankan aspek amanah seperti dijelaskan subjek Ketua Satgas Heroe Poerwadi.

"Seperti kebijakan PSBB, di Kota Yogyakarta sulit bisa menerapkan PSBB total. Karena, memang ekonomi di Kota Yogyakarta lebih banyak mikro. Jika hal tersebut dilakukan, pasti yang dirugikan masyarakat. Makanya, kami sampaikan, ternyata masyarakat berkeinginan untuk mikro lockdown atau membatasi akses masuk ke kampung-kampung dengan hanya satu pintu masuk dan dijaga. Alhamdulillah, kebijakan yang berlangsung sampai Agustus itu cukup efektif. Tidak terjadi lonjakan kasus".

Komitmen dalam menjaga penularan virus Covid-19 juga dilakukan dalam hal penegakkan peraturan. Itu dilakukan Satpol PP saat menghadapi deklarasi KAMI di Gedung PDHI Alun-Alun Utara dengan lebih mengawasi pelaksanaan acara agar prokes dan kerumunan bisa terhindarkan.

"Kami awasi kegiatan, dan alhamdulillah kegiatan tidak sampai menimbulkan kerumunan karena langsung bubar. Meski, saat itu ada benturan kepentingan politik, karena pihak Keraton sempat menolak kegiatan tersebut. Tapi, karena sudah mengantongi izin dan persyaratan ya, kami kawal agar tidak merugikan semua pihak.

Dinas Kesehatan Kota Yogyakarta juga menerapkan komitmen dan profesionalitas. Kepala Dinas Kesehatan Emma Rahmi Aryani menjelaskan komitmen tersebut.

"Kami melaksanakan kebijakan sebenarnya semuanya sudah dalam aturan. Baik itu dari Kementrian Kesehatan maupun pemerintah daerah. Kami lakukan sesuai instruksi yang diberikan. Karena, memang kami juga harus mempertanggungjawabkan semua yang kami lakukan. Seperti tracing, awal dulu dari satu orang positif kami bisa menelusuri 30 orang kontak erat. Saat ini, memang ada aturan, tapi tetap jika memang ada kontak erat yang mengaku bergejala langsung kami swab PCR".

Ketua LPMK Hariyanto menjelaskan profesionalitas menjadi pilar pihaknya bekerja. Misalnya,

"Pengurus di wilayah melakukan pengawasan terhadap warganya dengan melekat seperti kejaksaan waskat. Aktivitas masyarakat atau keluraga yang 
memiliki anggotanya rentan, harus terlaporkan. Kalau yang lain (warga yang tidak memiliki penyakit penyerta atau rentan), ya antisipasi dengan kesadaran menerapkan protokol kesehatan".

2. Aspek Tabligh

Menurut (Budiharto \& Himam, 2006), keterampilan komunikasi (communication skills) sebagai istilah kunci aspek tabligh. Kemampuan komunikasi yang efektif inilah yang akan menggerakkan masyarakat untuk bisa mengikuti petunjuk pemimpin.

Seperti Satgas Penanganan Covid-19 yang menjadikan Heroe Poerwadi sebagai Ketua Satgas dan Wakil Wali Kota sebagai juru bicara kepada masyarakat.

"Kemudian, jika masyarakat sudah mengerti apa yang sedang terjadi, kami menginformasikan kebijakan apa yang akan dilakukan. Semua informasi itu saya sampaikan melalui whatsapp grup di forum LPMK, forum RW, dan RT. Informasinya bersifat top down, dari grup di balai kota, kemudian camat, ke lurah, dan seterusnya sampai ke masyarakat".

“...Informasi yang diberikan ini semuanya, dari mulai anggaran yang ada lalu, kebijakan pemerintah pusat, DIY, dan kebijakan dari pemkot. Kalau memang berbeda, kami sampaikan alasannya. Akan tetapi, dari kebijakan yang kami lakukan memang tetap harus mengikuti aturan di atasnya. Mungkin, kami lebih mempertimbangkan aspek kearifan lokal...".

Kepala Dinas Satpol PP Kota Yogyakarta Agus Winarto menjelaskan, komunikasi menjadi salah satu hal yang harus dilakukan anggotanya dalam menegakkan peraturan.

"Dalam melaksanakan operasi yustisi, kami sering mempertimbangkan dampak penyebarannya. Misalnya, jika terjadi penyebaran bagaimana tracing jika sulit dilakukan ya terpaksa kami bubarkan. Jadi, jika hanya warung makan atau wisatawan selama masih bisa dipertanggungjawabkan siapa yang datang, kami berikan keleluasaan dan kami ingatkan agar masker tidak pernah dilepas serta menjaga diri dari kerumunan....”.

Kepala Dinas Kesehatan Emma Rahmi Aryani juga melakukan hal yang sama. Komunikasi kepada stake holder di bidang kesehatan merupakan Langkah efektif dalam menekan penyebaran virus Covid-19.

“...Kami sampaikan apa adanya kondisi keuangannya, dan alhamdulillah, banyak masyarakat yang peduli dengan membelikan APD untuk nakes (tenaga kesehatan)".

Satgas Penanganan Covid-19 di level bawah juga melakukan hal yang sama. Mereka lebih mengedepankan komunikasi dengan perangkat maupun masyarakat langsung.

"Setiap ada perkembangan (terhadap kebijakan penanganan virus) kami selalu berusaha untuk mengumpulkan masukan dari masyarakat. Bagaimana keinginan mereka? Bagaimana jika pemerintah misalnya lockdown? Kami 
himpun semua masukan, biasanya langsung itu di grup WA dan ada respon dari Pak Heroe. Kalau sangat penting dan misalnya ada khususan menyangkut satu wilayah kami minta waktu dan mendampingi pemangku wilayah untuk menyampaikan secara langsung".

3. Aspek Fathonah

Merujuk (Budiharto \& Himam, 2006), fathonah merupakan salah satu dari kecerdasan profetik yang menjadi dasar dari kemampuan mengatasi masalah (problem solver).

Satgas Penanganan Covid-19 mendasarkan fathonah dalam semua pekerjaannya mengingat dampak pandemi yang menimpa multi bidang, sehingga kecerdasan mengatasi masalah memiliki peran utama dalam penanganan Covid-19.

Ketua Satgas Penanganan Covid-19 Heroe Poerwadi menjelaskan, gotongroyong warga Kota Yogyakarta yang tinggi

merupakan modal utama dalam mengatasi dampak Covid-19 dan penyebarannya.

".. Makanya, sesuai arahan dari Pak Gub, kami lebih banyak memberdayakan masyarakat. Seperti kegiatan masak untuk warga, saat itu diawali dari Kampung Bausasran, ada petani sayur yang hanya ingin rumahnya hijau saja. Panennya meminta warga yang membutuhkan untuk memetik. Itu direspon oleh ibu-ibu Semaki Gede untuk dimasak di balai RW, hasilnya diberikan kepada masyarakat yang membutuhkan, seperti mahasiswa, warga yang kehilangan pekerjaan, dan lainnya".

"Kemudian, cantelan sayur, diawali oleh ibu-ibu yang sebelumnya kami gerakkan dalam kampung sayur, memanen hasilnya untuk cantelan di semua wilayah di Kota Yogyakarta. Alhamdulillah, lurah saya minta menghitung perputaran uangnya saat itu, bisa mencapai Rp 8,5 miliar yang semuanya berasal dari masyarakat untuk masyarakat sendiri”".

Kepala Dinas Satpol PP Agus Winarto menjelaskan, penerapan di lapangan selalu ada kendala. Apalagi, sejak September, masyarakat sudah lama tidak mendapatkan penghasilan, untuk menaati protokol kesehatan harus ada solusi antara kepentingan ekonomi dan virus tetap ditekan tidak menyebar.

" Penindakan juga tergantung dengan situasi di lapangan. Kalau memang pedagang bisa menjalankan take away. Khusus pasar misalnya, biasanya kami minta penjual untuk meminta pembeli mencatat pembeliannya dalam kertas agar tidak menimbulkan kerumunan, mereka kami minta jalan lagi. Nanti pulang tinggal ambil".

Kepala Dinas Kesehatan Kota Yogyakarta Emma Rahmi Aryani mengatakan, sebagai fasilitator pihaknya harus bisa mencarikan jalan keluar dari setiap masalah yang dalam kondisi pandemi saat ini kesehatan menjadi ujung tombak. 
" Untuk kasus adanya pasien ICU yang ditolak memang sempat ada kendala. Itu terjadi karena saat itu semua rumah sakit di Kota Yogyakarta tidak terintegrasi. Jadi, ketika ada pasien ditolak di RS Panti Rapih misalnya, itu tidak dikomunikasikan ke RS Bethesda. Padahal, kalau dikomunikasikan secara terintegrasi masih bisa tertampung.

Ketua LPMK Kota Yogyakarta Hariyanto menjelaskan, Satgas Penanganan Covid-19 menceritakan proses mencari solusi atas persoalan ekonomi di masyarakat.

"Di masyarakat sejak awal sudah ada pemahaman bergotong royong, mulai dari pembatasan akses masuk kampung (micro lockdown), cantelan sayur, menciptakan kampung sayur untuk dipanen bersama, sampai pemberdayaan lele. Itu hampir di semua wilayah. Karena, Pak Heroe langsung yang memotivasi, mengawasi, sampai ikut memanen".

"Kami di LPMK memiliki agenda bersama dengan Pak Heroe setiap hari Jumat bersepeda ke kampung-kampung. Hasilnya memang bisa dilihat, bersepedanya sekarang bisa dijual untuk paket wisata, wilayah juga memberdayakan masyarakat, mulai menanam sayur, menebar benih lele dengan kolam terpal dan selokan pengairan".

\section{B. Pembahasan}

Pandemi Covid-19 menuntut masyarakat dunia untuk bisa beradaptasi dengan tatanan baru. Teori kepemimpinan demokratis yang memberikan kebebasan kepada masyarakat atau orang yang dipimpin saat pandemi menjadi tidak efektif untuk masyarakat yang secara demografi ketertibannya rendah, seperti halnya beberapa wilayah di Indonesia yang masih untuk menerapkan ketertiban saja sulit, apalagi membangun kesadaran bahaya Covid-19.

Berbeda dengan wilayah lain, Kota Yogyakarta yang memiliki tingkat pendidikan 52 persen SLTP ke atas serta kondisi sosial yang banyak berdiri perguruan tinggi memiliki keuntungan dalam hal kesadaran masyarakat. Pengambil kebijakan akhirnya menjadi penentu terhadap kebijakan tersebut.

Tujuan penelitian ini adalah untuk mengeksplorasi, mengungkapkan serta mendeskripsikan kepemimpinan profetik Satgas Penanganan Covid-19 dengan memperhatikan kendala yang terjadi di lapangan dalam menerapkan aspek profetik tersebut. Untuk mencapai tujuan tersebut, observasi telah dilakukan sejak awal pandemi, wawancara terhadap ketia subjek dan satu significant others yang menjadi pelaku dari pemutus kebijakan, pelaksana kebijakan, dan objek dari kebijakan tersebut.

Satgas Penanganan Covid-19 menerapkan kepemimpinan profetik menyesuaikan dengan tugasnya yang telah diatur dalam SE Mendagri No 440/5184/SJ. Sesuai dengan ketugasan, keempat aspek kepemimpinan profetik yaitu Sidiq, Amanah, Tabligh, dan Fathonah menjadi inti dari ketugasan.

Aspek Sidiq saat terjadi krisis pandemi ini berguna untuk menjaga kejujuran informasi kepada publik (Lee, Morling, dan Bhopal, 2020). Di Satgas Penanganan 
Covid-19 Kota Yogyakarta, Heroe Poerwadi menjadi juru bicara bertujuan semua informasi bisa ia sampaikan dengan apa adanya. Khusus untuk informasi publik ini Heroe memang mengambil langkah satu pintu. Ia tidak mau informasi yang disampaikan Satgas Penanganan Covid-19 berbeda-beda antara bidang yang satu dengan yang lain yang bisa menyebabkan kebingungan di masyarakat.

Dalam penegakkan hukum yang bertujuan menertibkan masyarakat menjalankan protokol kesehatan demi mencegah penyebaran virus, faktor aspek sidiq yaitu integritas merupakan poin penting dalam menjalankan tugas Satgas. Petugas penegakkan hukum yang merupakan gabungan dari kepolisian, TNI, dan Satpol PP menerapkan aturan secara adil. Integritas petugas penegakkan hukum menurut Adinugroho dan Simanjuntak (2020), mampu meningkatkan optimisme masyarakat dalam menghadapi Covid-19.

Subjek ketiga yaitu Kepala Dinas Kesehatan Kota Yogyakarta Emma Rahmi Aryani menerapkan kejujuran dan integritas dalam kaitannya menangani pasien positif. Jumlah pasien yang positif, diagnosa pasien, sampai dengan koordinasi diantara rumah sakit rujukan menjunjung tinggi prinsip kejujuran dan integritas. Penanganan Covid-19 menuntut pelayanan kesehatan benar-benar menerapkan profesionalismenya berupa kejujuran dan integritas (Hamid, 2020).

Satgas Penanganan Covid-19 di tingkat terkecil yaitu RT dan RW di Kota Yogyakarta menerapkan aspek sidiq ini dalam hal penyaluran bantuan sosial. Ketua LPMK se-Kota Yogyakarta Hariyanto menegaskan, kejujuran menjadi pondasi dalam menyalurkan bantuan sosial agar tidak menimbulkan kecemburuan.

Aspek Amanah di Satgas Penanganan Covid-19 terjadi dalam hal menentukan kebijakan. Satgas selalu memperhatikan masukan dari masyarakat sebelum memutuskan kebijakan. Ketua Satgas Heroe Poerwadi meminta masukan masyarakat dengan membuka komunikasi terbuka di whatsapp group RW dan LPMK. Di grup pesan singkat tersebut, Heroe membuka kesempatan bagi masyarakat untuk memberikan masukan. Ia juga memberikan waktu khusus bagi mereka jika menurut masyarakat penting untuk disampaikan langsung kepadanya di rumah dinas wakil wali kota.

(Budiharto \& Himam, 2006) menjelaskan, amanah bagi pemimpin adalah menganggap kepemimpinan sebagai tugas, ujian, tanggung jawab dari Tuhan, yang pelaksanaannya tidak hanya dipertanggungjawabkan kepada para anggota yang dipimpin, tetapi juga kepada Allah SWT.

Bagian penegakkan hukum, menjalankan amanah artinya benar-benar menegakkan aturan dengan memperhatikan realitas di lapangan. Berdasarkan cerita dari Agus Winarto, Satgas dua kali sempat mendapatkan ujian dalam menegakkan amanah. Yaitu pertama kali saat kegiatan deklarasi ormas politik KAMI di Gedung PDHI Alun-Alun Utara dan penerapan PTKM (Pembatasan Terbatas Kegiatan Masyarakat) di Malioboro.

Satgas untuk kegiatan deklarasi ormas politik KAMI mampu menjaga pelaksanaan acara tetap menaati peraturan yaitu protokol kesehatan dengan ketat 
dan meminimalisir terjadinya kerumunan masyarakat yang banyak. Kasus kedua, Satgas Kota Yogyakarta sempat mendapatkan masukan dari Satgas tingkat provinsi untuk memberikan keleluasaan operasional toko dan PKL di Malioboro di malam hari yang akhirnya demi menjaga kondusivitas masyarakat tidak memberikan kekhususan di Malioboro.

Amanah atau dapat dipercaya, pada Dinas Kesehatan dengan memberikan pelayanan prima bagi pasien dan tenaga kehesetan. Seperti di awal Covid-19 menyiapkan fasilitas untuk tempat tinggal bagi nakes yang menangani langsung pasien positif Covid-19. Amanah membuat pemimpin bisa menjalankan komunikasi yang jelas sesuai hasil penelitian psikologis yang telah dilakukan dengan memperhatikan aspek transparansi, kejujuran, dan empati (Abram 2020).

Dalam menghadapi krisis pemimpin harus amanah yang berarti bisa bersikap terbuka atau transparan yang menjadi dua hal terpenting untuk menjaga kepercayaan masyarakat. LPMK Kota Yogyakarta menekankan kepada RW dan LMPK di masing-masing kelurahan untuk mendengar apa keluhan masyaraka agar kebijakan nantinya bisa mewakili keinginan dari masyarakat. Amanah berfungsi menjaga kepercayaan dari masyarakat atas apa yang disampaikan pemimpin jika mereka memberikan akses informasi, kebebasan untuk berbicara, mengajukan pertanyaan, bersedia menjawab pertanyaan, dan memberikan informasi perkembangan dengan benar (Ahern dan Loh, 2020).

Aspek Tabligh dalam penanganan Covid-19 merupakan bagian terpenting untuk bisa membangun kesadaran masyarakat. Di Kota Yogyakarta dalam menjalankan aspek tabligh ini begitu memiliki faktor pendukung tingkat pendidikan masyarakat dan gotong-royong. Heroe Poerwadi menyadari dua keunggulan tersebut yang kemudian dimanfaatkan untuk mendorong masyarakat di Kota Yogyakarta bisa lebih berdaya menghadapi Covid-19.

Satgas Penanganan Covid-19 membangun kesadaran akan bahaya penyebaran Covid-19 ini dengan mengembangkan micro lockdown di perkampungan. Masyarakat yang menjaga sendiri anggotanya dengan mengurangi keluar rumah saat awal wabah pada Maret 2020 sampai Agustus 2020.

Di bidang ekonomi, faktor pendukung tabligh ini menjadi titik awal Satgas Penanganan Covid-19 membentuk ketangguhan ekonomi. Satgas memberdayakan masyarakat untuk memanfaatkan sayur hasil tanam PKK dan warga untuk kemudian mereka kembangkan menjadi cantelan sayur di semua tempat di Kota Yogyakarta.

Langkah menerapkan aspek tabligh ini Satgas lakukan dengan mendampingi langsung proses pemberdayaan masyarakat. Ketua LPMK Hariyanto mengakui, LPMK memilki kegiatan langsung dengan Ketua Satgas Penanganan Covid-19 yang itu memudahkan penyampaian pesan kepada masyarakat. Karena, jika terjadi kendala Satgas bersedia untuk bertemu langsung dengan masyarakat. Hal tersebut yang kemudian memudahkan pengurus wilayah dalam menjaga warganya.

Keterampilan komunikasi atau tabligh ini menjadi salah satu tahap awal dari Satgas Penanganan Covid-19 di bidang penegakkan hukum. Langkah awal, Satgas 
akan membangun kesadaran masyarakat akan bahaya Covid-19. Hal tersebut mereka lakukan kepada setiap pelanggar baik individu maupun usaha. Dalam penyampaian ini pun, Satpol PP Kota Yogyakarta bertindak dengan ekstrem. Mereka membuat sandiwara dengan melepaskan pasien Covid-19 yang dikejar petugas dengan APD lengkap di wilayah yang kesadaran warganya menerapkan protokol kesehatan rendah. Hasilnya, program tersebut cukup efektif dan membuat warga semakin peduli terhadap dirinya sendiri dan orang lain terhadap penyebaran Covid-19.

Keterampilan komunikasi ini menjadi salah satu faktor penting dalam meningkatkan kesadaran masyarakat akan bahaya dari Covid-19. Keterampilan komunikasi bisa menekan angka sebaran virus karena masing-masing masyarakat tanpa perlu dilakukan tindakan penertiban bagi pelanggar mereka sudah tertib. Setelah masyarakat tertib, kebersamaan masyarakat dalam memerangi bersama Covid-19 bisa efektif dilakukan (Wilson, 2020).

Keterampilan komunikasi tidak hanya menuntut Satgas Penanganan Covid-19 untuk bisa menjalankan komunikasi yang efektif kepada masyarakat. Membuka hati dengan mendengarkan masukan dari orang lain baik itu ahli dan masyarakat dalam memberikan masukan juga menjadi bagian dari keterampilan komunikasi yang harus dilakukan ditahap awal. Jika sudah mendengar, masukan tersebut menjadi bahan pertimbangan untuk kemudian menjadi keputusan (Rahayuningsih, 2017).

Aspek Fathonah merupakan bagian terakhir dari kepemimpinan profetik. Fathonah yang berarti bijaksana dengan bisa mengambil hikmah atas apa yang terjadi atau cerdas dalam mencari solusi atas permasalahan merupakan wujud dari kematangan seseorang (Mansyur, 2013). Di Satgas Penanganan Covid-19 Kota Yogyakarta, aspek fathonah banyak dijumpai dari berbagai bidang.

Diantaranya bidang informasi publik, penanganan kesehatan, sampai penegakkan hukum, semuanya mengedepankan aspek fathonah dalam menyelesaikan permasalahan yang ada. Seperti Satgas Penanganan Covid-19 saat menyampaikan informasi, untuk mendapatkan kepercayaan masyarakat juru bicara langsung diambil Ketua Satgas yang juga menjabat Kepala Daerah. Kebijaksanaan tersebut otomatis berdampak langsung di masyarakat.

Aspek fathonah juga dilakukan dalam hal penegakkan hukum. Satgas Penanganan Covid-19 mempertimbangkan keterbatasan anggaran untuk menerapkan PSBB (Pembatasan Sosial Berskala Besar) yang sampai saat ini belum pernah diberlakukan di DIY maupun Kota Yogyakarta. Aspek fathonah berperan dengan kemudian mendorong masyarakat untuk mengawasi lingkungannya masing-masing.

Kebijaksanaan muncul karena adanya rasa empati atas apa yang terjadi. Satgas Penanganan Covid-19 Kota Yogyakarta benar-benar mengedepankan empati dalam penanganan dampak Covid-19. Di bidang ekonomi, dengan keterbatasan anggaran yang dimiliki Ketua Satgas Penanganan Covid-19 Kota Yogyakarta Heroe Poerwadi mengambil kebijaksanaan pemberdayaan masyarakat untuk saling bergeotong-royong membantu di lingkungan masing-masing. 
Keputusan ini ternyata efektif karena gotong-royong berupa gerakan mbagei yaitu berbagi terhadap tetangga mampu menjadi gerakan efektif dalam menangani dampak ekonomi. Kemudian, ngluwihi yang berupa gerakan untuk memberikan uang lebih bagi penjual maupun menambahkan dagangan bagi pembeli dari harga yang disepakati.

Di bidang penegakkan hukum, pengambilan keputusan yang bijaksana kerap mereka lakukan dengan membuat keputusan yang tidak memberatkan masyarakat. Seperti saat penegakkan aturan, Satpol PP Kota Yogyakarta bersama dengan polisi dan TNI kerap mengambil langkah tegas bagi usaha yang jelas-jelas melanggar karena menimbulkan kerumunan.

Di bidang kesehatan, aspek fathonah mereka lakukan saat terjadi permasalahan di lapangan, Kepala Dinas Kesehatan Kota Yogyakarta Emma Rahmi Aryani menhgungkapkan, kebijaksanaan mereka lakukan salah satunya dengan membuat sistem yang terintegrasi diantara tujuh rumah sakit di Kota Yogyakarta yang menjadi rujukan Covid-19. Mereka membuat sistem informasi agar pasien Covid-19 tidak tertolak saat akan mengakses fasilitas kesehatan. Jika salah satu rumah sakit penuh, mereka bisa mendapatkan informasi rumah sakit mana yang masih bisa menampung pasien.

Di masyarakat, aspek fathonah ini menciptakan jalan keluar dalam mengatasi permasalahan peningkatan pengangguran dan pendapatan masyarakat. Di lingkungan dengan dorongan dari Satgas Penanganan Covid-19, mereka bisa mendapatkan bantuan makanan yang merupakan implementasi dari gerakan mbagei dan ngluwihi. Dua gerakan ini berhasil menciptakan rasa empati dan saling peduli dengan bentuk cantelan sayur yang merata di semua tempat di Kota Yogyakarta.

Kecerdasan terutama secara psikologis, menjadi pilar utama dalam menangani pandemi ini agar bisa efektif dalam menekan penyebaran virus dan dampaknya. Kerendahan hati merupakan dasar bagi pemimpin agar bisa mendengar oleh para ahli mengenai kondisi dan mencari solusi saat terjadi krisis pandemi yang belum tahu kapan akan selesai, (Wilson, 2020).

Kecerdasan emosional menjadi salah aspek terpenting kepemimpinan saat masa krisis (Clark, 2020) Goleman (2000), kecerdasan emosional adalah kemampuan yang dimiliki seseorang dalam memotivasi diri, ketahanan dalam menghadapi kegagalan, mengendalikan emosi dan menunda kepuasan, serta mengatur keadaan jiwa.

\section{Kesimpulan.}

Penelitian ini mengungkapkan kepemimpinan profetik Satgas Penanganan Covid19 dengan memusatkan diri secara intensif pada satu obyek tertentu yang mempelajarinya sebagai suatu kasus. Data studi kasus diperoleh dari semua pihak yang bersangkutan atau dikumpulkan dari berbagai sumber.

Beberapa aspek kepemimpinan diidentifikasi sebagai aspek profetik, seperti siddiq yang berarti jujur, berkata benar, berintegritas, kemudian amanah atau bisa dipercaya, ia 
bisa menjalankan sebaik mungkin apa yang diamanatkan atau dipercayakan kepadanya. Dua aspek kepemimpinan lainnya adalah fathanah yang artinya cerdas atau pandai, serta Tabligh artinya adalah menyampaikan menyampaikan firman Allah yang diturunkan kepada umatnya. Kini, pengertian Tabligh mengalami perubahan makna lebih luas lagi, yaitu mampu menterjemahkan ajaran agama Islam dan diaplikasikan dalam kehidupan sehari-hari.

Kepemimpinan profetik adalah kemampuan mengendalikan diri dan mempengaruhi orang lain dengan tulus untuk mencapai tujuan bersama sebagaimana dilakukan oleh para nabi. Dimensi kepemimpinan profetik terdiri dari empat aspek, yaitu sidiq, amanah, tabligh, dan fathonah.

Secara umum, Satgas Penanganan Covid-19 bisa menerapkan keempat aspek penanganan Covid-19 dengan efektif di lapangan. Keempat aspek tersebut juga sesuai dengan ketugasan Satgas antara lain data dan informasi publik, peneggakkan hukum, dan penanganan kesehatan. Ketiga hal tersebut dalam pelaksanaan di lapangan membutuhkan keempat aspek kepemimpinan profetik yang saling berkaitan.

Aspek kejujuran, integritas, dapat dipercaya, merupakan modal dalam menjalankan tugas Satgas Penanganan Covid-19 di lapangan. Jika salah satu aspek tidak dilaksanakan, aspek lain seperti tablig menyebarkan informasi sulit dipercaya masyarakat. Begitu pun dengan aspek fathonah, jika tidak ada kejujuran, integritas dan dapat dipercaya, Satgas Penanganan Covid-19 bakal tidak bisa mencari jalan keluar dari sebuah permasalah. Jalan keluar yang dilaksanakan menjadi masalah baru di masyarakat. 


\section{BIBLIOGRAFI}

Adz Dzaky HB, Budiharto S, Kurniawan IN, Riyono B. (2005). Prophetic Intellegence. Jurnal Psikologi Islam Vol 1. No 1

Arikunto, Suharsimi. (2019). Prosedur penelitian suatu pendekatan praktik. Bandung: Rosdakarya.

Budiharto, Sus, \& Himam, Fathul. (2006). Konstruk teoritis dan pengukuran kepemimpinan profetik. Jurnal Psikologi, 33(2), 133-145.

Fadhli, Muhammad. "Internalisasi Nilai-Nilai Kepemimpinan Profetik dalam Lembaga Pendidikan Islam.” Jurnal Ilmu Pendidikan Agama Islam 10, no. 2 (2018): 117127.

Guest, Jodie L., Del Rio, Carlos, \& Sanchez, Travis. (2020). The three steps needed to end the COVID-19 pandemic: bold public health leadership, rapid innovations, and courageous political will. JMIR Public Health and Surveillance, 6(2), e19043.

Haÿry, M. A. T. T. I. (2020). The COVID-19 Pandemic: Healthcare Crisis Leadership as Ethics Communication. Cambridge Quarterly of Healthcare Ethics, 1-9. https://doi.org/10.1017/S0963180120000444

Maheran Nik Muhammad, N. (2015). Prophetic Leadership Model : Conceptualizing a Prophet' s Leadership Behaviour, Leader - Follower Mutuality and Altruism to Decision Making Quality. European Journal of Interdisciplinary Studies, 3(1), 93106.

Mansyur, Ahmad Yasser. (2013). Personal prophetic leadership sebagai model pendidikan karakter intrinsik atasi korupsi. Jurnal Pendidikan Karakter, (1).

Mas'udi, Wawan, \& Winanti, Poppy S. (n.d.). Bab 1 New Normal.

Moleong, Lexy J. (2019). Metodologi penelitian kualitatif.

Nawawi, H., Osman, N. S., Annuar, R., Khalid, B. A. K., \& Yusoff, K. (2003). Soluble intercellular adhesion molecule-1 and interleukin-6 levels reflect endothelial dysfunction in patients with primary hypercholesterolaemia treated with atorvastatin. Atherosclerosis, 169(2), 283-291.

Rahayuningsih, Tri. (2017). Kepemimpinan Profetik, Budaya Organisasi, dan Komitmen Organisasi Karyawan Universitas Abdurrab. Jurnal Psikologi, 12(2), $117-121$.

Riyono B. 2015. Kepemimpinan Transformasional Kebangkitan Kembali Studi Kepemimpinan.

Susanto SR. 2020. Germany's Strategy in Handling COVID-19: The Role of National 
Heri Susanto, Hadi Suyono, Khoiruddin Bashori dan Nina Zulida Situmorang

Leadership Strength and The Maximization of Welfare State Continental System Support.

Wilson, Suze. (2020). Pandemic leadership: lessons from New Zealand's approach to COVID-19. Leadership, 16(3), 279-293.

Yukl G, Mahsud R, Hassan S, Prussia GE. 2013. An Improved Measure of Ethical Leadership. https://doi.org/10.1177/154805181142935 